\title{
Vernakulaarin monta tasoa
}

\author{
Näkökulmia Matthias Salamniuksen runoon Ilo-Laulu Jesuxesta
}

Eeva-Liisa Bastman, Kati Kallio ja Tuomas M. S. Lehtonen

$I^{\prime}$

Imaisumuotojen tai ilmaisullisten rekisterien merkitykset, käyttötavat ja status vaihtele-

vat ajan kuluessa kielestä, lajista ja tilanteesta toiseen siirtyessään; itse muotokin tunnuspiirteineen elää, ja uusia syntyy. Asif Agha (2007, 55-77) on analysoinut tämänkaltaisia prosesseja rekisteriytymisen (enregisterment) käsitteen avulla. Etenkin pidempien historiallisten kehityskulkujen yhteydessä piirtyy usein esiin muodon vaihtuvia assosioitumisia korkean ja matalan, eliitin ja kansan, virallisen ja epävirallisen, muodollisen ja epämuodollisen, juhlavan ja arkisen piiriin. Näitä siirtymiä on viime aikoina tarkasteltu esimerkiksi suullisen ja kirjallisen välisen vuorovaikutuksen sekä kirjallistumisen tutkimuksen saroilla (esim. Kallio et al. 2017; Laitinen ja Mikkola 2013). Sanaparien jälkimmäiset osat - matala, kansa, epävirallinen, suullinen, epämuodollinen, arkinen - ovat puolestaan viime aikoina tulleet käsitellyiksi myös vernakulaarin käsitteen alla (esim. Noyes 2012; Howard 2008).

Suomenkielisen runouden kaksi päämuotoa eli riimillinen säkeistömuotoinen runous ja riimitön kalevalamitta ovat 1500-luvulta lähtien tallentuneen historiansa kuluessa liikkuneet monin eri tavoin korkean ja matalan, suullisen ja kirjallisen välillä - ja välillä liukuneet toisiinsa erilaisissa hybridisissä eli kummankin muodon piirteitä yhdistävissä runoissa. Runouden ja runomuotojen kirjallistumisen historia näiden kahden sangen erilaisen, mutta paikoin toisiinsa sekoittuvan muotokielen monisyisenä rinnakkaiselona ja vuorovaikutuksena on mainio kenttä myös vernakulaarin käsitteen tarkempaan pohdintaan. Vernakulaari hahmottuu nimittäin eri tavoin riippuen siitä, katsotaanko sitä kirjallisuustieteen vai folkloristiikan kannalta. Kirjallisuustieteessä kyse on yleensä kansankielisestä, paikallisesta tai tietyn alaryhmän kirjallisuudesta, folkloristiikassa taas kansanomaisesta, epävirallisesta, ei-institutionaalisesta, usein suullisestakin ilmaisusta. Näitä yhdistää vernakulaarin pitkä käsitehistoria sekä ajatus kansankielisestä, epävirallisesta ja hierarkkisesti alisteisesta. Käytännön analyysissa näkökulmat täydentävät toisiaan, mutta edellyttävät myös vernakulaaria tarkempien määreiden käyttöä.

Tässä artikkelissa tarkastelemme suomenkielisen runouden ja kirjallistumisen historiaa vernakulaarin käsitteen ja konkreettisen tapauksen kautta. Analysoimme luterilaisen kirkonmiehen Matthias Salamniuksen vuonna 1690 ilmestynyttä kalevalamittaista kristillistä eeposta Ilo-Laulu Jesuxesta, joka asettuu monisyisellä tavalla osaksi kirjallistumisen, kansanomaistamisen ja runokielten suullisen ja kirjallisen käytön historiaa. Ilo-Laulu on kirjallinen runo, joka on laadittu suullisen runon mittaa ja poetiikkaa noudattaen. 2265-säkeinen teos 
on ensimmäinen laaja kirjoitettu kalevalamittainen kertova runo, ensimmäinen suomenkielinen kirjoitettu eepos. Se kuvaa Jeesuksen syntymän ja elämänkulun keskeiset vaiheet ja opastaa hartauskirjalliseen tapaan lukijaa ristinkärsimyksen, kuoleman ja ylösnousemuksen oikeaoppiseen tarkasteluun. (Bastman 2019.)

Pohjanmaalla syntyneen, Inkerissä apupappina toimineen Salamniuksen (1640-1690) runoelma asettuu suhteeseen niin paikallisen suullisen tradition kuin kirjallisen kosmopoliittisen tradition kanssa. Runon laji, Kristuksen elämästä, kärsimyksestä ja kuolemasta kertova eepos, kuuluu jälkimmäisen piiriin. Perinteinen suullinen kalevalamitta alkusointuineen, parallelismeineen, poetiikkoineen ja potentiaalisine esitystapoineen puolestaan edustaa paikallista kansankielistä traditiota. Kalevalamittaa oli ennen Salamniusta hyödynnetty erilaisissa kirjallisissa hybridimuodoissa, joihin yleensä kuului riimi ja muita perinteisestä suullisesta muodosta poikkeavia piirteitä, mutta perinteisen riimittömän mitan kirjallinen käyttö oli vielä harvinaista. Ilo-Laulusta tuli pidetty teos sekä rahvaan että eliitin parissa. Seuraavina vuosisatoina siitä otettiin ainakin yhdeksäntoista painosta, viimeisimmät 1960-luvulla. 1700-luvun lopulla H. G. Porthan (1983) käytti sitä laajalti esimerkkinä kuvatessaan suomalaista poetiikkaa ja runolaulua, ja sata vuotta myöhemmin esimerkiksi Julius Krohn (1862) ja August Ahlqvist (1877) mainitsevat sen edelleen lukijoiden ja tutkijoiden arvostamana korkeatasoisena runona.

Artikkelissa pohdimme Salamniuksen Ilo-Laulua esimerkkinä käyttäen, minkälaisia näkymiä vernakulaarin käsite avaa runokielten käyttöön ja muokkaamiseen liittyviin prosesseihin sekä riimillisen laulun ja kalevalamitan väliseen dynamiikkaan. Pohdimme samalla, miten kirjallisuustieteen ja folkloristiikan vernakulaari haastavat tai täydentävät toisiaan. Aloitamme esittelemällä käsitteen historiaa sekä nykykäyttöä folkloristiikan ja kirjallisuudentutkimuksen piirissä - etenkin folkloristiikan piirissä käytyjä keskusteluita tarkastellaan pidemmälti muissa tämän numeron artikkeleissa. Ensimmäinen analyysiluku tarkastelee Ilo-Laulua suhteessa kansankielisen kirjallisuuden luomisprosesseihin, yleisemmin suomen kielen kirjallistumisprosessien suhteita suulliseen kulttuuriin ja Salamniuksen asemaa tässä. Kolmannessa luvussa käsittelemme Ilo-laulun oppineita ja kansanomaisia vastaanottoja, ja neljännessä teosta osana vuosisataisia runokielten rekisteriytymisprosesseja.

\section{Vernakulaari folkloristiikassa ja kirjallisuudentutkimuksessa}

Vernakulaarin käsite juontuu naispuolisen kotiorjan eli vernan kieltä tai puheenpartta tarkoittavasta latinankielen sanasta. Myöhemmin se yleistyi tarkoittamaan Euroopan eri alueiden kansankieliä ensisijaisesti latinan mutta myös muiden oppineiden kirjakielten kuten kreikan vastakohtana. Antiikin maailmassa halpa-arvoista kotikutoisuutta tarkoittanut termi muuttui ensin kielten ja ilmaisutapojen erilaisuutta ja hierarkioita merkitseväksi sanaksi. Ensisijaisesti vernakulaarilla tarkoitettiin Euroopan keski- ja uuden ajan kansankieliä ja niiden kirjallisuuksia. Tässä merkityksessä se on ollut yleinen kielen- ja kirjallisuudentutkimuksessa. H. G. Porthan $(1766,3,6)$ käyttää adjektiiviä vernaculus 1700 -luvun lopulla kansankielisyyden merkityksessä suomalaisia runomuotoja kuvatessaan. 1960-luvulla termi otettiin käyttöön antropologiassa ja rakennuskulttuurien nimeämisessä ja ulotettiin myös ei-kielelliseen inhimilliseen toimintaan. Englanninkielisissä sanakirjoissa vernakulaari määrittyy kansankieleksi tai kansankieliseksi, mutta myös laajemmin kansanomaiseksi, tietylle alueelle tai ryhmälle tyypilliseksi, epämuodolliseksi, standardoimattomaksi, puhekieliseksi tai kollektiiviseksi. Se voidaan myös asettaa liturgisen, kirjallisen, muodollisen, oppineen, sivistyneen 
tai vieraskielisen vastakohdaksi. (Oxford English Dictionary: vernacular; Merriam-Webster: vernacular). Se voi siis arkikielessä tarkoittaa hyvin monenlaisia asioita.

Viime vuosikymmeninä käsitettä on käytetty enenevässä määrin folkloristiikan piirissä tarkoittamassa institutionaalisen ja muodollisen vastakohdaksi asettuvaa, tietyn ryhmän jakamaa ja ylläpitämää omaehtoista, epävirallista, spontaania tai arkista kulttuuria (Bauman 2016; Howard 2008; Noyes 2012; 2016). Vaikka se korvaa erilaisia ongelmalliseksi muuttuneita kansa-sanan johdannaisia ja kantaa yhä mukanaan ajatusta yhteiskunnallisista hierarkioista, se on samalla tuonut keskusteluun uuden ulottuvuuden. Vernakulaarin kielellinen tai kulttuurinen käyttö viittaa ennemminkin ilmaisutavan luonteeseen kuin käytäjän kuulumiseen johonkin tiettyyn ryhmään. Niinpä se ainakin jossain määrin vapauttaa kulttuurisen ilmaisun sitomisesta tiettyyn yhteiskunnalliseen ilmaisijaan ja hänen asemaansa. Vernakulaari kielenkäytön tai kulttuurisen ilmaisun tapa on enemmän ilmaisurekisterin (ks. Agha 2004; Koski 2016, 127-128; Koski ja Turtiainen 2020) kaltainen ilmiö: yksilöt voivat käyttää, valita ja vaihdella ilmaisun tapoja, mutta ne saattavat käyttäjäyhteisönsä piirissä assosioitua tiettyihin tyypillisiin tilanteisiin, käyttäjäryhmiin ja kulttuurisiin merkityksiin. Folkloristiikassa ja lingvistisessä antropologiassa kulttuuriset ilmiöt kytketään usein ajatukseen niitä ylläpitävistä ja uusintavista - joskus myös kiistävistä - yhteisöistä. Kielitieteen piiristä lähteneellä puheyhteisön käsitteellä viitataan yhteisöön, joka jakaa samanlaisia, joskaan ei ristiriidattomia kielenkäytön tapoja (rekistereitä) ja näihin liittyviä käsityksiä (ks. Agha 2004). Folkloristiikan piirissä käytyjä keskusteluja vernakulaarin käsitteestä ja sen edeltäjistä tarkastellaan laajemmin tämän Eloren numeron kahdessa muussa artikkelissa (Hämäläinen et al. 2020; Koski ja Turtiainen 2020).

Kirjallisuudentutkimuksessa vernakulaarin käsitteellä on viitattu alkujaan kansankielen käyttöön kirjoitetun kirjallisuuden kielenä (esim. Copeland 1991, Arner 2013). Amerikkalaisessa kirjallisuudentutkimuksessa ja Pohjois-Amerikan tutkimuksessa yleisemmin (American Studies) vernakulaarin käsite otettiin käyttöön 1950-luvulla puhuttaessa arkikielisen tyylin (colloquial style) käytöstä kirjallisuuden kielenä (Lemke 2009). Rinnan kirjallisuudentutkimuksen kanssa käsitettä on käytetty pohjoisamerikkalaisen kulttuurintutkimuksen piirissä. Esimerkiksi jazzin ja populaarimusiikin kehitystä ja niiden suhdetta eurooppalaiseen taidemusiikkiin on jäsennetty puhumalla "amerikkalaisesta vernakulaarista" (American vernacular), joka rakentui suullisen ja usein sosiaalisesti alempien (erityisesti afroamerikkalaisten) ryhmien ilmaisuperinteen varaan (Green 1993, 35-46; ks. myös Gioa 2011).

Kirjallisuudentutkimuksessa vernakulaari sai uusia merkityssisältöjä 1990-luvulla osana postkolonialistisen teorian kehittymistä. Kansallisen ideologiaa ja yhtenäisyyden kulttuuria purkaneet tutkimussuuntaukset, kuten dekonstruktio, feministinen tutkimus ja postkolonialismi, ovat saaneet jatkokseen niin kutsutun transnationaalisen käänteen, ja kansallisesti rajattujen aineistojen ja tutkimuskysymysten sijaan tarkastelun kohteeksi on otettu kirjallisuuden kohtaaminen ylikansallisten ilmiöiden kanssa. (Ks. Pollari et al. 2015; Grönstrand et al. 2016; Jay 2010.) Globaalilla mittakaavalla operoivan, monikulttuurisen ja monikielisen kulttuurin tutkimuksessa vernakulaari on muodostunut paikallisuuteen viittaavaksi käsitteeksi, jonka avulla paikallinen on erotettavissa kansallisesta tai ylikansallisesta kulttuurista (Lemke 2009; Leppänen 2018). Myös kirjallisuudentutkimuksessa vernakulaarin käsitteeseen sisältyy siis kytkös kirjallisuuden ilmaisumuotojen ja yhteiskunnallisten hierarkioiden välillä. 
Vertailevaa historiallista otetta edustavat Alexander Beecroft (2015) ja Sidney Pollock (2000) tarkastelevat vernakularisaatiota suullisen ja kirjallisen kulttuurin välisiä suhteita jäsentävänä historiallisena prosessina. Vernakularisaatio johtaa kirjakielen luomiseen paikallisesta puhutusta kielestä, hallitsevan kosmopoliittisen kielen malleja noudattaen (Beecroft 2015, 147). Pollock korostaa vernakularisaatiota tekemisenä, uutena tapana toimia kotoperäisillä kielillä kirjoitettujen tekstien kanssa (Pollock 2000, 606). Kyse on tietoisesta uuden kirjallisuuden luomisesta ja uudenlaisen kirjallisen ilmaisun kehittämisestä kansankielen lähtökohdista käsin, mutta suhteessa hallitsevan kosmopoliittisen kielen tarjoamiin malleihin.

Alexander Beecroft kuvaa teoksessaan An Ecology of World Literature (2015), kuinka ajatus "vernakulaarista", kirjaimellisesti käännettynä kotikutoisesta tai omaehtoisesta kulttuurista, kielestä ja kirjallisuudesta, on syntynyt moneen kertaan vanhan maailman sivilisaatioissa Kiinasta ja Intiasta Eurooppaan. Sen lähtökohtana on ollut oppineen eliitin kielen ja kulttuurin erkaantuminen paikallisesta kielestä ja kulttuurista oppineiston omaksuessa kosmopoliittisen erityiskielen kuten mandariinikiinan, sanskriitin tai kreikan. Antiikin välimerellisessä maailmassa kreikka oli eliitin sivistyskieli, ja se säilyi sellaisena läpi Rooman valtakunnan mahtiaikojen. Latina edusti yhtä monista vernakulaareista, vaikka se kirjallistui ja nousi vallan kieleksi. Latinan termi vernaculus viittaa arkiseen kotiorjien kieleen ja sitä käytettiin myös tarkoittamaan Rooman kaupungille ominaista kielenpartta. Keskiajalla läntisen kristikunnan piirissä uskonnollisen kultin ja kirkollisen hallinnon kieleksi omaksuttu latina muuttui lopulta kosmopoliittiseksi oppineiden ja eliittien sivistyskieleksi.

Matthias Salamniuksen Ilo-Laulu oli osa suomenkielistä kirjallistumisen prosessia ja kansankielisen kirjallisuuden luomista, eli vernakularisaatiota Beecroftin ja Pollockin tarkoittamassa merkityksessä. Eri aikoina ja eri kulttuureissa vernakularisaation prosessit eivät noudata samaa kaavaa, vaikka tiettyjä yhdistäviä tekijöitä voidaan Beecroftin mukaan tunnistaa. Usein vernakularisaatio liittyy nimenomaan puhutun paikalliskielen aseman muuttumiseen, ja sen taustalla vaikuttavat paikallisen hallinnon muodostuminen sekä uusien uskonnollisten liikkeiden nousu. (Beecroft 2015, 149.) Nämä tekijät vaikuttivat vernakularisaatioon myös varhaisen uuden ajan Suomessa. Ruotsin valtakunta oli irrottautunut Kustaa Vaasan johdolla Kalmarin unionista ja alkanut kehittyä keskitetymmäksi valtioksi. Kuningas oli halunnut myös latinankielisen kirkon omaisuuksineen otteeseensa, mikä osaltaan vaikutti reformaation hyväksymisen taustalla. Kielten käyttötavat järjestyivät osin uudenlaisella tavalla. Ruotsi oli toiminut hallinnon kielenä aikaisemminkin, mutta reformaation ja hallinnon keskittymisen myötä sen asema vahvistui. Suomen kieli siirtyi suullisesta kielestä myös uskonnollisen kirjallisuuden ja jumalanpalvelusten kieleksi. Latina pysyi oppineiden ja kirkon kansainvälisenä kielenä. (Heikkilä 2010; Kallio et al. 2017, 12, 26-34; ks. myös Burke 2004.)

Beecroftilla vernakulaarin käsite liittyy hänen esittämäänsä teoriaan kirjallisuuden globaalista kierrosta, leviämisestä ja liikkeestä, ja tästä johtuen hänen näkemyksensä vernakulaarista korostaa kirjallistumisen näkökulmaa. Kirjoitetulla tekstillä on erilaiset edellytykset säilymiseen, leviämiseen ja auktorisoidun aseman saavuttamiseen kuin suullisella ilmaisulla. Siihen, minkälaista kirjallisuutta kulttuuri synnyttää, minkälaisen aseman se saa ja miten sitä kierrätetään, vaikuttavat suullisen tai kirjallisen muodon ohella lukuisat muutkin seikat: kielellinen, poliittinen ja taloudellinen tilanne sekä uskonto ja kulttuuripolitiikka. Nämä yhdessä luovat biomin eli eloyhteisön, joka Beecroftin mukaan selittää, miksi tietyt kulttuurit tiettyinä historiallisina aikoina tuottavat tietynlaista kirjallisuutta. (Beecroft 2015, 11, 25-27.) Beecroft tarkastelee vernakulaaria ensisijaisesti suhteessa kosmopoliittiseen kulttuuriin ja 
kirjallisuuteen, eikä huomioi suullisen kulttuurin roolia. Esimerkiksi Ruth Finnegan (1977, 16-24, 160-169) on korostanut kulttuuristen kontekstien sekä suullisen ja kirjallisen välisten vuorovaikutussuhteiden moninaisuutta.

Beecroft erottaa toisistaan vernakularisaation kaksi keskeistä vaihetta: kirjallistumisen (literization) ja kirjallisuudellistumisen (literarization). Kirjallistuminen tarkoittaa puhutun kielen saattamista kirjoitettuun muotoon, eli sillä viitataan kirjakielen muodostumiseen. Sen kriteereitä ovat esimerkiksi aakkosten ja oikeinkirjoitusjärjestelmän kehittäminen ja käyttöönotto. Kirjallistuminen ei vielä johda siihen, että kieli otettaisiin käyttöön kirjoitetun runouden kielenä: yleensä kirjoitusjärjestelmän kehittymisen syyt ovat käytännönläheisempiä ja liittyvät esimerkiksi hallinnon tai uskonnon tarpeisiin. Kirjallisuudellistumisella tarkoitetaan kielen esteettisten resurssien kehittymistä sellaisiksi, että kieli sopii käytettäväksi kirjoitetun sanataiteen kielenä. Beecroftin mukaan kielen muodostuminen täysmittaiseksi vernakulaariksi kieleksi edellyttää, että se käy läpi sekä kirjallistumisen että kirjallisuudellistumisen vaiheet. (Beecroft 2015, 150-151.)

\section{Ilo-Laulu Jesuxesta ja kansankielisen kirjallisuuden luominen}

Suomen kielen kirjallistuminen käynnistyi jo keskiajalla, vaikka tästä ei ole paljonkaan säilyneitä lähteitä. Keskiajallakin oli saarnattu ja opetettu kansankielellä, ja pappeja esimerkiksi oli kehotettu kirjoittamaan ylös keskeisimmät opinkappaleet eli Isä meidän -rukous, Ave Maria, uskontunnustus sekä ripittäytymisen kaava, jotta he pystyisivät toistamaan ne seurakunnalle aina samalla tavoin ja ne opittaisiin paremmin (Heininen 2007, 42). Myös uskonnollinen kirkollinen suomen kieli kehittyi keskiajan kuluessa (Heikkilä 2010). Laajamittaisemmin suomen kielen kirjallistuminen alkoi kuitenkin vasta reformaation myötä uudelle ajalle tultaessa. Se suomen kieli, joka syntyi kirjallistumisen varhaisessa vaiheessa 1500-luvulla, oli erilaista kuin puhuttu kieli: se pohjasi länsimurteisiin ja ruotsin kielestä omaksuttuihin rakenteisiin. Jo varhaisella uudella ajalla kieli alettiin kuitenkin ymmärtää yhteisenä suomen kielenä huolimatta kirjakielen ja paikallisten puhekielten eroista. (Mikkola ja Laitinen 2013, 436-438.)

Kirjallistuminen eteni reformaation vauhdittamana, uskonnollisen ja kirkollisen elämän ohjauksessa. Prosessi alkoi jumalanpalveluksessa ja kansanopetuksessa tarvittavien keskeisimpien tekstien suomentamisena. Ensimmäiset suomenkieliset painetut tekstit olivat pitkälti proosaa tai psalmien ja Raamattuun pohjaavien vapaamittaisten laulutekstien kaltaista proosarunoa, ja keskeisenä tavoitteena oli reformoitujen uskonnollisten sisältöjen välittäminen kansalle. (Häkkinen 2012a.) Yksi Mikael Agricolan julkaisemista ensimmäisistä kirjoista oli Abckiria, jonka tarkoitus oli toimia sekä lukutaidon että kristinuskon perusteiden opetuksessa (Häkkinen 2015, 53-57). 1600-luvulle tultaessa ilmestyivät ensimmäiset suomen kielen kieliopit ja latina-ruotsi-sanakirja, jossa myös suomi ja saksa olivat mukana (Lauerma 2012). Jo 1500-luvun lopulta on säilynyt myös suomenkielisiä kuninkaan kiertokirjeitä eli kirkossa kansalle ääneen luettavaksi tarkoitettuja hallinnollisia tekstejä (Heikkilä 2010).

Suomalaisen kirjallisuudellistumisen eli runouden ilmaisukeinojen kehittämisen ja vakiinnuttamisen prosessin varhaisimmat vaiheet kytkeytyvät nekin reformaatioon. Raamattuun sisältyy myös psalmien kaltaisia poeettisia tekstejä, joten Raamatun tekstien kääntäminen merkitsi myös ensimmäisten kirjoitettujen runosuomennosten ilmestymistä. Samalla ilmestyivät ensimmäiset omaperäiset kirjalliset runot: Agricola varusti osan teoksistaan riimillisistä 
väljistä parisäkeistä koostuvilla esipuherunoilla (Häkkinen 2012b). Varsinaisesti säkeistömuotoisten, loppusoinnullisten ja sanapainoon perustuvien mittojen omaksuminen kirjalliseen suomen kieleen käynnistyi virsirunouden myötä. Jacobus Finno kertoo ensimmäisen suomenkielisen virsikirjan esipuheessa riimin käytön olleen hyvin tietoinen teko: hän halusi levittää kotiseurakuntiinsa samanlaisen, yhtä vetovoimaisen kristillisen laulukulttuurin kuin oli nähnyt vallitsevan saksankielisillä luterilaisilla seuduilla (Lehtonen 2016). Virsirunous oli kiinteästi sidoksissa paitsi Raamatun teksteihin, myös monikielisten esikuvien poetiikkaan sekä erilaisiin säe- ja säkeistörakenteisiin, jotka puolestaan olivat sidoksissa myös sävelmiin (Kurvinen 1929; Laitinen 2005, 153; Kallio 2016). Ensimmäiset kirjalliset runot eivät käyttäneet perinteistä suullista runomuotoa, vaan toivat suomen kieleen uusia runouden malleja.

Suomen kielen vanhemman metrisen systeemin eli kalevalamitan omaksuminen kirjoitettuun runouteen käynnistyi hieman myöhemmin. Muotoa ei otettu kirjalliseen käyttöön sellaisenaan. 1660-luvulle asti kirjoitettu suomenkielinen runo on riimillistä silloinkin, kun se käyttää kalevalamitalle tyypillisiä piirteitä. Ensimmäiset kaksi tunnettua kalevalamitan piirteitä ja riimiä yhdistävää kirkollista laulua ovat säilyneet käsikirjoituksena Tukholman suomenkielisestä seurakunnasta 1580-luvulta (Rapola 1934). Kuuluisin esimerkki on Ericus Justanderin riimiä ja kalevalamitan piirteitä yhdistävä onnitteluruno kuningas Kaarle X Kustaan häihin vuodelta 1654 (Melander 1941, 15, 54; Sarajas 1954, 54). 1600-luvun puolivälin jälkeen julkaistiin myös pidempiä opettavia hybridimuotoisia runoja, merkittävimpinä Suomen kirkollisen historian esittävä Ajan-Tieto (1658) ja kristillinen opetusruno Huonen-Speili (1699) (Kallio et al. 2017, 352-354). Kalevalamitalle ominaisia tavunpituussääntöjä noudatetaan näissä oppineissa runoissa yleensä vain osin, ja joitain suullisen mitan piirteitä, kuten alkusointua tai säkeiden säännöllisyyttä liioitellaan. Riimin ja kalevalamitan piirteiden yhdistämistä on mahdollista tarkastella myös suullisen mitan kirjallistamisena ja kirjallisuudellistamisena: vanhaa suomalaista suullisen runon muotoa muokattiin aikakauden kirjallisiin tarpeisiin sopivaksi. (Kallio 2017.)

Ilo-Laulu oli osa tätä kirjallisuudellistumisen ja kirjallisen runouden luomisen jatkumoa, mutta myös selkeä käännekohta: ensimmäinen suullisen kaltaisella riimittömällä kalevalamitalla kirjoitettu laajemmalle yleisölle suunnattu painotuote. Riimitöntä kalevalamittaa esiintyi 1600-luvun jälkipuoliskolla lähinnä melko suppealevikkisissä henkilörunoissa. Salamnius itse käytti sitä piispa Gezelius vanhemman muistorunossa vuonna 1690. (Melander 1928, 16.)

Huolimatta kansanomaisen mitan käytöstä Salamniuksen runo on läpikotaisin kirjallinen, institutionaalinen, kristillinen ja luterilainen. Teoksen ensipainoksen oppineessa esipuheessa Salamnius kertoo laatineensa teoksen kiitollisuuden osoituksena Jeesukselle. Hän mainitsee myös Turun tuoreen piispa Johannes Gezelius nuoremman neuvonantajanaan ja suojelijanaan. Gezelius on antanut julkaista teoksen omalla kustannuksellaan "toiwoden Että JEsuxen Christuxen tundemus tällä tawalla yxinkertaisen cansan tykönä parenbaan muistoon tulis." (Salamnius 1690.) Runon "Pani präntihin Turussa / Johan Winter, winhiästi" (mts., kansilehti) piispa Gezelius vanhemman perustamassa kirjapainossa, joka Tuija Laineen (2007) mukaan painoi erityisesti "uskonnollista peruskirjallisuutta ja oppikirjoja" sekä kuninkaallisia asetuksia. Esipuheessaan Salamnius siis asettaa teoksen kristillisen ylistyksen ja kansanopetuksen kehyksiin. Ilo-Laululla on myös suora kytkös kirjallistumisen varhaisemman vaiheen teoksiin. Sisällön ja rakenteen osalta runo pohjaa Mikael Agricolan evankeliumipohjaiseen kärsimyshistoriaan Se meiden herran Jesusen Christusen pina, ylesnousemus ia 
taiuaisen astumus (1549), joka sisältyi hieman toimitettuna myös 1600-luvun Manuale-käsikirjoihin (Bastman 2019; Laine 1997, 51, 141).

Salamniuksen Ilo-Laulua voidaankin esipuheensa perusteella tarkastella myös osana luterilaisen kansanopetuksen hanketta ja luterilaisen ortodoksian ajan ponnisteluja lukutaidon ja kansanopetuksen edistämiseksi (ks. Laine ja Laine 2010). Piispan tuella "yxinkertaiselle cansalle" suunnattu runoteos, jonka oli tarkoitus lisätä kristinuskon perusteiden tuntemusta, oli viisainta laatia kansan kielellä ja kansan itsensä käyttämällä runomuodolla, kirkon auktorisoimaan Agricolan passioharmoniaan tukeutuen.

Uskonnon ja vernakularisaation välinen side on monissa kulttuureissa ollut vahva eikä suomen kieli tee tässä suhteessa poikkeusta. Varhaisimpia vernakulaarilla kielillä laadittuja teoksia ovat usein saarnakokoelmat, erilaiset käsikirjat ja käytännön uskonelämän tarpeisiin laaditut teokset. Näitä kaikkia oli jo ennen Salamniusta laadittu myös Suomessa. (Laine 1997.) Kansankielisen uskonnollisen kirjallisuuden tarve on Beecroftin mukaan usein kehittänyt ja rikastuttanut kieltä tavalla, joka edistää myös kirjallisuudellistumista. Kirjallistuminen uskonnollisin perustein ei kuitenkaan automaattisesti johda kirjallisuudellistumiseen. Beecroft korostaa, että sen paremmin uskonnolliset motiivit kuin kansallinen ideologia, johon vernakularisaatio on kansallisesti suuntautuneissa tutkimustraditioissa tavallisesti yhdistetty, eivät yksinään riitä selittämään vernakularisaatiota ilmiönä ja prosessina. Kansankielen käyttöön liittyy aina myös esteettisiä ja mahdollisesti myös poliittisia ulottuvuuksia. (Beecroft 2015, 148-153.)

Varhaisen uuden ajan Suomessa suomen kielen asema latinaan ja ruotsiin nähden oli heikko. Kirjallisen runouden kielenä suomi vakiintui papiston käyttöön 1600-luvun aikana, mutta jäi selvästi ruotsia vähemmälle käytölle 1700-luvulle tultaessa. Kulttuurissa, jossa runous oli paljolti meritoitumisen, virkauran edistämisen ja tuttavuussuhteiden vaalimisen väline, ruotsin tai latinan käyttöön liittyi enemmän prestiisiä. Suomen kielen korkeakirjalliselle käytölle ei yksinkertaisesti ollut kannustimia. (Lilius 1994, 59-61.) Oppineisto toimi koko valtakunnan kattavassa ja sen rajojen ylikin ulottuvassa monikielisessä suhteiden verkostossa: pitäytyminen suomen kielessä tarkoitti siten pitäytymistä hyvin paikallisella tasolla. Uskonnon ja paikallisen kansanopetuksen saralla suomen kielen käyttö oli kuitenkin välttämätöntä.

Ilo-Laululla on siten vahva kytkös kirkon kansanopetukseen ja uskonnollisen elämän tarpeita palvelevaan kirjallisuuteen - mutta samalla se on jo runomuotonsakin takia kaunokirjallinen teos. Tätä Salamnius (1690) itsekin korostaa puhuessaan esipuheessaan "Runoi wärsyistä" ja "yxinkertaisen Puheen" kääntämisestä "suloisexi lauluxi". Varhaisella uudella ajalla kaunokirjallisuutta ei nähty erillisenä lajina, vaan kaikki kirjallisuus oli osa julkisen sanan käytön aluetta, ja sen esitystapaa sääteli retoriikan normisto. Poeettisten tekstien muodossa ja esitystavassa esteettisyys korostuu kuitenkin erityisellä tavalla. Varhainen kirjoitettu runous eroaa myöhemmästä kaunokirjallisuudesta myös tarkoitusperiltään: runoteoksen tuli käyttää kaunista ja puhuttelevaa kieltä, mutta sen tuli samalla myös opettaa ja viihdyttää. (Hansson 2000, 9-12.) Ilo-Laulun opetukselliset ja hartaudelliset tarkoitusperät tuodaan ilmi teoksen esipuheessa ja opettavaisessa päätösluvussa, jossa lukijaa opastetaan Jeesuksen kärsimyksen ja kuoleman oikeaoppiseen tarkasteluun (Salamnius 1690). Lajipiirteiltään runo muistuttaa eniten raamatullista epiikkaa, joka kuului suosituimpiin runon lajeihin 1500- ja 1600-luvun eurooppalaisessa kirjallisuudessa (ks. Bastman 2019). 
Beecroftin mukaan keskeinen piirre vernakulaarissa kirjallisuudessa on, että se syntyy kilpailemaan kosmopoliittisen kulttuurin kanssa (Beecroft 2015, 153). Myös Salamniuksen runo haastaa samasta aiheesta aiemmin laaditut kirjalliset esitykset tarttuessaan yhteen 1600luvun suosituimmista kirjallisista aiheista, Jeesuksen kuolemaan ja ylösnousemukseen. Aikakauden kulttuuriin kuuluneen jäljittelyn ja kilpailun elementin onkin katsottu merkittävällä tavalla edistäneen kansankielistä kirjallisuutta: jäljiteltävät teokset asettivat tason, jonne ja jonka yli kansankielisen kirjallisuudenkin oli pyrittävä. (Cullhed 2002; ks. tarkemmin Bastman 2019.)

Vernakulaarin kirjallisuuden synty edellyttää, että kansankielellä on käytössään riittävät kulttuuriset resurssit (Beecroft 2015, 34). Tällaisia resursseja voivat olla esimerkiksi tekstin kirjoittamiseen ja kirjalliseen levittämiseen vaadittavat teknologiat tai lukutaitoinen yleisö, mutta myös poeettiset resurssit, kuten runokielen ilmaisurikkaus ja käyttökelpoisuus. Tarvittavat käytännön teknologiat olivat 1600-luvun lopulla jo täysin saatavilla vakiintuneesta kieliasusta kirjapainoihin. Yleisö ei vielä ollut täysin lukutaitoista, mutta lukutaito oli kyllin levinnyt, jotta painotuotteiden sisällöt levisivät lukutaitoisten kautta lukutaidottomillekin (ks. Kuha 2016, 108; Laine 1997). Runokielet olivat monimuotoisessa muokkautumis- ja määrittelyprosessissa, jossa suomen kieleen oli jo ainakin sataviisikymmentä vuotta sovitettu keskieurooppalaisen riimillisen säkeistölaulun malleja. Salamniuksen runo kuitenkin osaltaan näyttää, että 1600-luvun lopulla suullinen kalevalamittainen runokieli oli kulttuurisena resurssina niin vakiintunut, monipuolinen ja ilmaisullisesti joustava, että se soveltui myös kristillisen kirjallisen eepoksen mitaksi. Tässä kohtaa kirjallisuudellistaminen ei siten tarkoittanut uuden kaunokirjallisen runomuodon kehittämistä, vaan jo kauan suullisena käytetyn runomuodon melko suoraa siirtämistä kirjallisuuden piiriin.

\section{Kirjallistumisen suhde suulliseen kansanomaiseen kulttuuriin}

Folkloristiikan kautta katsottuna vernakulaarin käsite ei asetu kuvaamaan Ilo-Laulua osana kirjallistumisprosessia tai kansankielistä kirjallisuutta, vaan sitä, miten Salamnius ottaa käyttöönsä suullisen, kansanomaisen tai epävirallisen eli vernakulaarin kulttuurin piirteitä ja miten hän asettaa oman kirjallisen, transnationaalehin aiheisiin ja perinteisiin nojaavan runonsa suhteessa tähän vernakulaariin paikalliseen kulttuuriin. Kansankielinen kirjallistuminen on tästä näkökulmasta katsottuna osa virallisia, kosmopoliittisia ja institutionaalisia prosesseja, mutta suhteessa paikallisiin suullisiin ja kansanomaisiin kielenkäytön tapoihin.

Ilo-Laulu tuo ensimmäistä kertaa riimittömän, suullisen kaltaisen kalevalamitan oppinutta piiriä laajemmalle yleisölle suunnattuun painotuotteeseen. Samalla se ottaa suullisen kansanomaisen runomuodon hyvin kirjallisten ja institutionaalisten, jo sata viisikymmentä vuotta aikaisemmin kansankielistettyjen kosmopoliittisten sisältöjen levittäjäksi. Suomenkielisen kirjallisen kulttuurin luomisessa käytettiin paitsi kansainvälisiä kirjallisia, myös paikallisia suullisia tai kansanomaisia resursseja. Ilmeisin tällainen resurssi on kieli käsitejärjestelmineen. Myös kalevalamitta oli käytettävissä oleva, mutta kirjallisuudellistumisprosessissa paikoin vältelty tai ainoastaan hybridimuodoissa eli riimillistettynä käytetty resurssi. Kirjallisen kulttuurin vernakularisaatio (siirtäminen kansankielelle) ei ollut vain uuden luomista tai latinankielisten sisältöjen kääntämistä: se oli myös suullisen kulttuurin piirteiden siirtämistä kirjallisiin muotoihin ja pyrkimystä toisten suullisen kulttuurin piirteiden syrjäyttämiseen. 
Virret olivat monilla kielialueilla keskeinen osa kansanopetusta ja kansankielisen kirjallisuuden luomista. Ilmiönä ne olivat samanaikaisesti kansankielinen, kansanomainen, suullinen, paikallinen, kirjallinen, institutionaalinen ja kosmopoliittinen. Keskiajalla riimilliset laulut eivät kuuluneet keskeisimmän liturgisen laulun piiriin, mutta reformaatio nosti ne jumalanpalveluksen ja kansanopetuksen keskiöön. Toisin kuin Suomessa, uudelle ajalle tultaessa riimillinen säkeistölaulu oli Keski-Euroopassa ja Ruotsissa myös kansanlaulun keskeisin muoto. Saksassa riimillisen kansankielisen laulun tuominen jumalanpalvelukseen tarkoitti vernakulaarin (sekä 'kansanomaisen' että 'kansankielisen') tuomista kosmopoliittisen kirkollisen kulttuurin piiriin. (Brown 2005; Herl 2004; Lilja 2006, 204-213.) Suomessa luterilaisen virsilaulun synty tarkoitti sitä vastoin uudenlaisen vernakulaarin ilmaisukielen ja poeettisen muodon luomista (Kurvinen 1929). Hemminki Maskulaisen virsikirjaan asti tässä prosessissa välteltiin kalevalamitan kaltaisia piirteitä (Lehtonen 2016). Maskulainen taas ikään kuin kotoperäisti virsilaulun yhdistämällä siihen joitain kalevalamitalle tyypillisiä piirteitä (Lehtonen ja Kallio 2017). Virsilaulun sovittaminen suomen kielelle oli siten samanaikaisesti kirjallisten sisältöjen ja toisten kielten kirjallisten ja suullistenkin piirteiden tuomista ja näiden suhteuttamista suomen kielen jo olemassa oleviin kielellisiin ja poeettisiin resursseihin.

Virret asettuvat suullisen ja kirjallisen runouden välimaastoon: vaikka niitä levitettiin ja luotiin kirjallisin keinoin, ne sepitettiin laulettaviksi ja sävelmiin sopiviksi (Laitinen 2005, 153). Vaikka virret olivat kansankielisiä ja kansaa opettamaan suunnattuja, niiden sisältö oli hyvin kirjallista ja sidoksissa Raamatun teksteihin, teologisiin keskusteluihin sekä kirkollisiin käytäntöihin ja rituaaleihin (esim. Kurvinen 1929; Kurvinen 1940). Ne olivat sekä vernakulaaria ('kansankielistä, paikallista') että kosmopoliittista kulttuuria: virsiä käännettiin samoilla säkeistö- ja mittarakenteilla samoihin sävelmiin kielestä toiseen. Toinen merkittävä, lähteisiin tallentunut 1600 -luvun suomenkielisen runouden laji eli kalevalamitan piirteitä käyttävät painetut onnittelurunot (ks. Melander 1929; 1941) näyttäytyvät puolestaan sangen kirjallisina runoina. Nekin tosin hyödynsivät suullisen kulttuurin poeettisia resursseja, ja on mahdollista, että niitä myös laulettiin. Ilo-laulu ei varsinaisesti lukeudu kumpaankaan näistä runouden lajeista.

Salamnius luo monessa mielessä uuden suomenkielisen kirjallisen lajin, vaikka ei itse eksplisiittisesti määritä tai nimeä sitä. Hän on otsikoinut runonsa Ilo-Lauluksi, mutta ei kuitenkaan teoksensa esipuheessa viittaa sen paremmin runon lukemiseen kuin laulamiseenkaan, eikä kytke teosta mihinkään olemassa olevaan kirjalliseen lajiin. Runomuodon puolesta lähin vertauskuva on Salamniuksen itsensä hieman ennen Ilo-Laulua riimittömälle kalevalamitalle kääntämä Johannes Gezelius vanhemman muistopuhe ja muutamat aiemmat pohjalaisten pappismiesten riimittömät tilapäärunot (Kuusi 1998; Melander 1929; 1941). Kun teoksen keskeisiä piirteitä katsoo kokonaisuutena, asettuu Salamniuksen runo pituudeltaan, aiheensa laajuudelta ja runomuodoltaan selkeästi erilleen niin virsilaulusta kuin oppineista tilapäärunoista ja muutamasta laajemmalle yleisölle suunnatusta kronikoivasta tai opettavasta runosta. Hänen luomallaan lajilla on kuitenkin vahva yhteys aiempaan ja ympäröivään suulliseen kulttuuriin.

Vaikka ei sano sitä suoraan, Salamnius näyttää ajatelleen Ilo-Laulunsa paitsi luettavaksi myös laulettavaksi. Teoksen nimi tietenkin viittaa tähän vahvasti - sana "laulu" ei vanhassa kirjasuomessa näytä viitanneen kirjalliseen runoon vaan nimenomaisesti laululyriikkaan tai laulamiseen (VKS: laulu). Laulettavuuteen viittaa myös Salamniuksen tapa sommitella teoksensa luvut yhden tapahtuman ja muutaman henkilöhahmon ympärille, mikä helpottaa 
sekä muistamista että tapahtumien kuulonvaraista hahmottamista. Myös Ilo-Laulun lukujen pituus, 31-156 säettä, vastaa tyypillistä suullisten kalevalamittaisten runojen pituutta myöhemmissä aineistoissa. Luvut selvästi soveltuivat myös lauluiksi.

1600-luvun kalevalamittaisesta suullisesta kulttuurista ei ole kattavia lähteitä, vaikka etenkin sananlaskuja ja loitsuja on tallentunut jonkin verran. Myöhempien lähteiden perusteella on selvää, että kalevalamitta kattoi laajan kirjon lajeja kertovasta runosta tanssilauluihin, sananlaskuihin, häälauluihin, kehtolauluihin, pilkkalauluihin ja arvoituksiin. Myöhemmät aineistot sisältävät maallisten ja esikristillisten aihelmien ohella sellaisia kalevalamittaisia runoja, joita on aiheidensa puolesta vaikea sijoittaa muualle kuin kristilliseen keskiaikaan, esimerkiksi keskiaikaista latinankielistä pyhimyselämäkertaa sivuava Piispa Henrikin surmavirsi, sekä pyhimysaiheita hyvin kansanomaisesti käsittelevät Mataleenan ja Tapanin virret sekä Katariinan poltto. Monet loitsut pyytävät apuun neitsyt Mariaa ja niissä on muitakin keskiajan kristillisyyteen viittaavia aihelmia: loitsutekstejä on 1600-luvultakin tallentunut oikeustapausten yhteydessä. (Kallio et al. 2017.) Historiallisissa lähteissä ei ole merkkejä siitä, että tämänkaltaisia suullisia runoja olisi sepitetty reformaation jälkeen. Näyttää siis siltä, että keskiajan kristillistymisen tuloksena suomen ja karjalan kielillä syntyi myös joukko kristillisiä kalevalamittaisia runoja ja aihelmia, jotka reformaation koittaessa olivat vakiintuneet osaksi kansankielistä suullista kulttuuria.

Jacobus Finno mainitsi virsikirjansa esipuheessa haluavansa korvata sopimattomat laulut virsilaululla. Kyseessä on yleinen Lutherilta peräisin oleva ajatus, joka ei liity tietyn muotoisten tai kielisten laulujen sopimattomuuteen, vaan eri tavoin sopimattomiin sisältöihin. (Lehtonen 2016, 193-199; Kallio et al. 2017, 104-124, erit. 111-114.) Vaikka muutamat 1600-luvun piispat näyttävät hyökkäävän kaikkea kansanomaista laulamista vastaan (ks. Sarajas 1954, 42), on todennäköistä, että osa kalevalamittaisesta runoudesta, kuten kehtolaulut, lorut tai maalliset kertovat laulut katsottiin harmittomiksi. Mitta itsessään ei missään nimessä ollut täysin tuomittava: sananlaskuissa sitä käyttivät myös suomalaiset piispat ja se kelpasi riimitettynä kirjallisen runouden rakennusaineeksi. Vuonna 1699 tuntematon henkilö kirjoitti kalevalamittaisen Kaarle-herttuan valloitusretkeä ylistävän runon Turun linnakirkon pöytäkirjojen sekaan. (Kallio et al. 2017.) Toki on myös ilmeistä, että näkemykset suomenkielisestä suullisesta perinteestä ja sen eri piirteiden käyttökelpoisuudesta tai kelvottomuudesta ovat voineet Agricolan ja Salamniuksen teosten välille sijoittuneella lähes sadanviidenkymmenen vuoden ajanjaksolla vaihdella paljonkin.

Salamniuksen asenne vernakulaariin laulukulttuuriin oli joka tapauksessa toisenlainen kuin Finnolla yli sata vuotta aikaisemmin. Hän ei pyrkinyt korvaamaan suosittua vernakulaaria suullista muotoa uudella, vaan käyttämään perinteistä suullista runomuotoa sellaisenaan kristillisen opetuksen välineenä. Salamnius oli tämän runomuodon suvereeni käyttäjä: muoto oli luultavasti tuttu jo lapsuudesta. Hän oli kotoisin Pohjois-Pohjanmaalta ja oli palvellut pappina Inkerissä: molemmat olivat seutuja, joissa kalevalamittainen runokulttuuri eli vahvana 1800-luvulle asti (Kuusi 1998). Juuri pohjalaiset papit olivat muutamia kymmeniä vuosia ennen Salamniusta alkaneet käyttää riimitöntä kalevalamittaa kirjallisissa runoissaan (Melander 1941, 16-17).

Tarve kansan valistamiseen oli myös Salamniuksen aikana erilainen kuin Finnon aikaan. Virsilaulu oli jo tullut suosituksi ja virsikirja oli yleisimpiä maallikoiden omistamia kirjoja. Luterilaisen ortodoksian kausi oli opettanut kansaa ja kitkenyt keskiaikaisia sopimattomiksi 
katsottuja tapoja. (Laine ja Laine 2010, 58-306.) Salamnius selvästikin tajusi, miten tehokas opettamisen, tiedon välittämisen ja kirjallistamisen väline vernakulaari runomuoto voisi olla. Esipuheessaan hän toteaa, että suomen kieli ja suomalaisen perinteisen runouden kieli oli yksi niistä kaikista kielistä, joilla Jumalaa tuli kiittää. Samalla hän kuitenkin katsoi tarpeelliseksi perustella pidemmin, että runomuodossa itsessään ei ollut vikaa, vaikka sillä oli sepitetty ja laulettu myös luvattomia asioita:

\begin{abstract}
Waan että tämä on tehty niillä suomalaisten tykönä hywin tutuilla Runoi wärsyillä / ei ole Ihmex otettava, Sillä niincuin muilla kielillä on heidän erinomainen wärsyiensä muoto / josa yxikertainen Puhe suloisexi lauluxi käätään / niin ei ole meidän Suomen=Kieli tätä asiasa wähin osasta / Ja waicka me sen kyllä tiedämme / että tämän caltaisten Runolauluin cautta on ennen monta luvatoinda Asia coconpandu ja laulettu / Niin taita se sitä wähemmän tätä edesottamista estä cuin että meidän pitäis sen yhteisen Puheen sentähden poisheittämähän / Että se usein wäärin käytetän. (Salamnius 1690, esipuhe.)
\end{abstract}

Salamnius ei tarkemmin avaa, minkälaisia luvattomia asioita tarkoittaa: paavillisia vai pakanallisia, maallisia vai uskonnollisia, vai kenties kaikenlaisia.

Salamniuksen kirjalliselle runolle on olemassa myös aiempi kansanomainen, suullinen vastineensa. Keskiaikaan liittyvien kristillisten kalevalamittaisten suullisten runojen joukossa on Luojan virren nimellä kulkeva sadunomainen, osin apokryfikertomuksiin nojaava sykli Jeesuksen syntymästä, katoamisesta ja Hiiden sepän kahlinnasta, joka SKVR-korpuksen hakemistossa kattaa runotyypit Marjavirsi, Saunanhakuvirsi, Lapsenetsintävirsi, Hiiden sepän kahlinta sekä Ylösnousemusvirsi. Myöhempinä vuosisatoina näitä runoja on tallennettu erilaisina versioina pääosin ortodoksialueilta Karjalasta ja Inkeristä. Ericus Erici Cajanus mainitsee Luojan virren arvostavasti vuonna 1697 väitöskirjassaan ja siteeraa kahta pohjoisille alueille tyypillistä alkusäettä (Sarajas 1956, 92-94). Kansanomainen runo oli siis paikallisille oppineille ja luultavasti Salamniuksellekin tuttu. Salamniuksen joitain sisällöllisiä valintoja voikin tulkita pyrkimyksenä korjata suullisessa perinteessä esiintyneitä vääriä käsityksiä. Siinä missä kansanrunous asettaa auringon aktiiviseksi, Jeesuksen pelastamiseen osallistuvaksi toimijaksi, Salamnius esimerkiksi korostaa auringon vain todistavan tapahtumia sivusta. Runokielen tasolla Salamnius ei näytä juurikaan tarvitsevan suullisessa runoudessa yleisiä ilmauksia ja säemalleja. Suullisten formuloiden käyttö on satunnaista. Paikoin Salamnius antaa perinteisille ilmauksille uusia tulkintoja: "Itse pilwiä pitäwä" ei ole kansanrunouden tavoin Ukko ylijumala (esim. SKVR XII2 5034), vaan seimessä makaava Jeesus-lapsi. (Bastman ja Kallio, tulossa.) Mahdollisesti Salamnius onkin pyrkinyt korvaamaan ja syrjäyttämään aiempaa kansanomaista runotraditiota omalla puhdasoppisella, laulettavissa olevalla luterilaisella versiollaan. Runon vastaanotto osoittaa, että jossain määrin näin tapahtuikin: Ilo-Laulun vaikutus näkyy myöhemmässä suullisessa runoudessa. Kirjoitetussa kirjallisuudessa kalevalamittainen runo on sitä vastoin ollut hyvin marginaalisessa asemassa.

\title{
Ilo-laulun vastaanotto ja vernakulaari haltuunotto
}

Tietoja Ilo-Laulun ilmestymisaikaisista käyttötavoista tai sitä koskevia varhaisia kirjallisia kommentteja ei ole säilynyt, joten teoksen vastaanottoa täytyy tarkastella osin epäsuorasti, myöhempien tai yleisempien lähteiden perusteella. Lukutaitoisen yleisön määrä ei 1690luvun Suomessa ollut suuri, mutta kirkko pyrki tietoisesti kasvattamaan hengellisiä tekstejä suomen kielellä lukevien joukkoa (Laine ja Laine 2010). Toisaalta runon laatiminen kansanomaista runomittaa ja poetiikkaa käyttäen mahdollisti myös runon suullisen omaksumisen. 
Vaikka teos edustaa kansankielistä kirjallisuutta, myös pääosin suullisen kulttuurin piirissä elänyt rahvas on voinut kokea sen omakseen. Ilo-Laulun kohdalla voidaankin puhua sekä teoksen kirjallisesta että suullisesta, oppineesta että vernakulaarista vastaanotosta.

Ilo-Laulusta ilmestyi toinen painos vuonna 1706 ja sen jälkeen huomattava määrä uusia painoksia 1700-luvun ja 1800-luvun kuluessa, mikä kertoo sen yleisestä suosiosta. Osaksi kirjallista vastaanottoa voidaan katsoa myös se, että 1700-luvulla riimittömien kalevalamittaisten kirjallisten runojen määrä lisääntyi, vaikka suomenkielisen runouden osuus Ruotsin valtakunnassa painetusta runouden kokonaismäärästä laski (ks. Niinimäki 2007, 307). Esimerkiksi vuonna 1700 julkaistiin arkkina kalevalamittainen kuningas Kaarle XII voittoa Narvassa ylistävä Ilo Laulu, Ylitzen Sen suloisen Woiton [...] Narwan Caupungin alla, jossa sekä nimen Ilo laulu että suullisen runomuodon käytön voi uumoilla ottaneen vaikutteita Salamniukselta (ks. Virrankoski 1968). Christfried Ganander (1786) puolestaan jatkoi raamatullisten tekstien kalevalamittaistamista lähes sata vuotta myöhemmin julkaisemalla esimerkiksi kalevalamittaisen Korkean veisun ja osan Jobin kirjaa (Laitinen 2006, 53).

Ilo-Laulun akateeminen vastaanotto käynnistyy Henrik Gabriel Porthanin myötä 1760-luvulla: De poësi Fennicassa (1766-1778; suomennos 1983) hän käyttää runsaasti Ilo-Laulun säkeitä esimerkkinä selittäessään suomenkielisen runouden eli kalevalamitan sääntöjä. Vuosisata myöhemmin August Ahlqvist $(1877,179-180)$ totesi Suomalaisessa runo-opissa, että vaikka teos oli painettu "ensi kerran jo vuonna 1690", se "joutui niin rakkaaksi kirjaksi Suomen kansalle, että tämä ei vieläkään ole herjennyt sitä lukemasta". Ahlqvist arvelee tämän johtuvat teoksen kristillisestä aiheesta sekä runon yksinkertaisesta, selkeästä ja eläväisestä esitystavasta ja kauniista kielestä. Uusintapainokset luonnollisesti helpottivat runon saatavuutta ja edesauttoivat sen säilymistä yleisön tietoisuudessa. Vielä 1800-luvun lopulla Salamniuksen runo esiintyy myös kirjastojen lainauslistoilla (ks. Luukkanen 2016, 368-369).

Tietoa siitä, miten Ilo-Laulua luettiin, laulettiin, levitettiin tai käytettiin 1700-luvulla, ei juuri ole. On mahdollista, että papisto käytti sitä tavalla tai toisella kansanopetuksen apuna, tai että seurakuntalaiset lukivat tai lauloivat sitä omassa keskuudessaan. Kirjallisen teoksen leviäminen ei edellytä koko yhteisön lukutaitoa. Keskiajan tutkija Brian Stock (1983) on jäsentänyt sydänkeskiaikaisia uskonnollisia yhteisöjä ja kerettiläisliikkeitä puhumalla "tekstuaalisista yhteisöistä" (textual communities). Yhteisöt muodostuivat tavallisesti yksittäisten lukuja joskus myös kirjoitustaitoisten tulkitsijoiden ympärille, jotka esittivät oman tulkintansa kristinuskon keskeisistä kirjoituksista, eli kulttuurisesti arvostetuista ja institutionalisoiduista teksteistä ja jotka usein haastoivat instituutioiden kuten kirkon aseman. Kirjallisten, institutionaalisten tekstien leviäminen ja vernakulaarien (epäinstitutionaalisten, suullisten) tulkintojen syntyprosessi edellytti vain yksittäisiä lukutaitoisia, suullisissa yhteisöissä toimivia ihmisiä. Tekstuaalisen yhteisön käsite rinnastuu myös lingvistisen antropologian puheyhteisön käsitteeseen: kuvatun kaltainen yhteisö jakoi paitsi käsityksiä ja tulkintoja tietyistä teksteistä myös erilaisia suullisen kommunikaation tapoja ja niitä koskevia käsityksiä. Myös hyväksytty valtainstituutio, kuten luterilainen seurakunta, muistuttaa Stockin tekstuaalista yhteisöä. Seurakunnan pappi tai joku muu luku- ja kirjoitustaitoinen toimi tulkitsijana ja välittäjänä kirjallisen ja suullisen kulttuurin risteyskohdassa. Salamniuksen Ilo-Laulun varhainen välittyminen on epäilemättä tällaisten yhteisöjen aiheuttamaa.

Kansa ja oppineetkin näyttävät ottaneen Ilo-Laulun vastaan myös lauluna. Porthanille tuntuu olevan itsestään selvää, että Ilo-Laulua on laulettu: hän siteeraa teoksen säkeitä myös 
selittäessään talonpoikaisia laulutapoja. (Laitinen 2006, 54.) Salamniuksen runoa ei koskaan painettu sanallisen sävelmäviitteen kera kuten laulettavaksi tarkoitettujen virsien tai arkkiveisujen painoksissa oli usein tapana. Tämä ei kuitenkaan tarkoita runon tulleen tulkituksi luettavana tai lausuttavana teoksena, sillä yleensäkin kalevalamittaiset laulut painettiin ilman sävelmäviitettä. Vain muutamassa myöhemmässä kalevalamittaisessa arkkiveisussa mainitaan, että ne tulee laulaa "runo-nuotilla" tai "tawallisella Runo-nuotilla", valtaosassa ei anneta sävelmäviitettä lainkaan. (Niinimäki 2007, 307.) Yleiset ja yksinkertaiset sävelmät oletettiin ilman muuta kaikille tutuiksi. Kun C. A. Gottlund (1847) julkaisi arkkipainoksena Vesilahdelta peräisin olevan suullisen kalevalamittaisen kertovan runon Elinan surma, hän kirjoitti ennen runoa ohjeen "Lauletaan kun llo-laulu Jesuksesta." 1800-luvun jälkipuoliskolla on myös tallennettu kaksi Ilo-Lauluun yhdistettyä runosävelmää, toinen Pohjois-Inkeristä ja toinen Keuruulta. Sävelmät ovat tyypillisiä viisi-iskuisia runosävelmiä, jota on voitu käyttää soololauluna tai vuorolauluna samaan tapaan kuin Porthan omassa teoksessaan kuvaa. Tämä on sävelmätyyppi, joka oppineissa käsityksissä suorastaan ikonisesti liitettiin vanhaan runoon. (Laitinen 2006, 54.) Se myös todella on Suomen alueen ja Vienan Karjalan yleisimmin tallennettu sävelmätyyppi (Launis 1930, numerot 242-611). Runomuodon sekä sille tyypillisten sävelmien ja esitystapojen osalta Salamniuksen runo solahti osaksi vernakulaaria suullista kulttuuria.

Vernakulaarista vastaanotosta kertoo osaltaan myös runon myöhempi suullinen käyttö. 1800-luvun runonkerääjät pyrkivät tallentamaan ainoastaan puhtaan suullista perinnettä, mutta tallensivat myös joitain kirjallisten runojen suullisia versioita, joko vahingossa tai tekstien variaation ja suullisten piirteiden takia. SKVR-korpuksesta löytyy esimerkiksi Pielavedeltä vuonna 1903 Antti Pääkköseltä, 13-vuotiaalta torpan pojalta tallennettu 21-säkeinen runo, jonka ylle on ilmeisesti kirjasarjan toimittaja kirjannut hakasulkuihin "Kirjallista vaikutusta. Vrt. Mattias Salamniuksen 'llolaulu Jesuksesta'". Runo onkin lähes kokonaan Salamniukselta, joskin yhdistelmä ensimmäistä ja neljättä lukua, ja jotkut säkeet ovat ottaneet hieman erilaisen muodon. Ensimmäinen säepari "Jouluna Jumala synty, paras poika pakkasella" esiintyy suullisessa perinteessä sekä itsenäisenä sananlaskuna että osasina Luojan virttä eri alueilla (esim. SKVR I2 1103; IV2 2051; VI2 6450), mutta ei Salamniuksella. Pääkkönen kertoi oppineensa runon Kiuruvedeltä kotoisin olevalta loiselta Elias Hujaselta, ilmeisesti suullisesti. Hyrynsalmella vuonna 1882 taas Kaarle Krohn kirjoitti Salmo Keräseltä muistiin proosaselityksillä lisätyt neljätoista säettä Hiiden sepän kahlinta -runoa, jonka alku noudattaa paikallista suullista traditiota, mutta yhdeksän viimeistä säettä periytyvät suoraan Salamniuksen luvusta 24, tosin uudenlaisessa järjestyksessä.

Runon osaset ja mukaelmat siis kulkivat myös suullisesti, joskus suullisiin Luojan virsi -sikermän aihelmiin sekoittuen. Ne lähtivät myös omille teilleen. Salamniuksen yksittäinen säe löytyy ilomantsilaisen Simana Sissosen Polvenhaava-loitsusta ja toinen Sammonryöstö-runosta (SKVR VII1 314, 680; Kuusi 1998).). Muutaman säkeen jaksoja löytyy myös omaelämäkerrallisen oloisesta lyyrisestä ketjusta Vuoleelta (SKVR V2 441) sekä kaipuuta, kuolemaa ja rakkautta käsittelevästä, kenties myös Kantelettaresta vaikutteita ottaneesta aihelmaketjusta llomantsista (SKVR VII2 1774). Suullinen kulttuuri käytti siis Salamniuksen ja muiden kirjallisten teosten säkeitä myös omiin tarkoituksiinsa, oman säevarantonsa osana. 


\section{Runokielten rekisteriytyminen}

Runokieli on monien tekijöiden summa, ja saman näköinen tai samalla nimityksellä kutsuttu runomuoto tai runouden elementti voi eri aikoina ja eri konteksteissa ottaa uusia muotoja tai tulla käytetyksi ja ymmärretyksi uusilla tavoilla. Tämänkaltaisia prosesseja on lingvistisessä antropologiassa käsitelty rekisteriytymisen käsitteen avulla. Rekisteri tarkoittaa sosiaalisesti jaettua tilanne- tai tarkoitussidonnaista ilmaisutapaa ja yhteneväisiä käsityksiä sen eri tilanteissa kantamista ja välittämistä merkityskentistä. Puheyhteisön jakamat käsitykset rekisteristä tai sen käyttötavat eivät välttämättä ole ristiriidattomia, ja yhteisön jäsenillä voi olla hyvin erilaisia rekisterin käytön kompetensseja. Rekisterien analyysiin on käytännössä kaksi toisiaan täydentävää keinoa: tarkastella sitä, mitä käyttäjät itse kertovat ilmaisutavoistaan ja niiden merkityksistä, ja tarkastella sitä, miten he ilmaisutapojaan käyttävät. (Agha 2004.) Rekisteriytymisellä (enregisterment) Asif Agha (2007, 55, ks. myös Lehtonen 2015, 38-50) tarkoittaa rekisterien syntymiseen ja määrittymiseen liittyviä sosiaalisia prosesseja. Rekisterien sosiaalinen määrittyminen tarkoittaa myös sitä, että ne ja niiden kantamat merkitykset voivat ajan kuluessa vaihdella. Nykylukija ei luultavasti liitä riimiin tai kalevalamittaan täysin samanlaisia merkityksiä tai sävyjä kuin August Ahlqvist, Matthias Salamnius tai Jacobus Finno.

Vaikka historiallisten lähteiden luonne tarkoittaa usein sitä, että rekisterien käytöstä ja rekisteriytymisen prosesseista jää paljon näkymättömiin, on yleistä kuvaa runomuotojen ja niiden ymmärtämisen muutosprosesseista mahdollista hahmotella. Säännöllinen riimi ja säkeistörakenne oli suomen kielellä Finnosta alkaen itseoikeutettu kirkollisen seurakuntalaulun muoto. Käsitykset runomuodon luonteesta olivat silti uuden ajan alussa liikkeessä, eikä riimillistä runoutta ehkä hahmotettu yhtenä selkeärajaisena rekisterinä. Riimilliset runomuodot olivat rantautuneet Skandinaviaan viimeistään 1320-luvulla, mutta helsinkiläissyntyinen Sigfrid Aronus Forsius kirjoitti vielä 1608 ruotsinkielisten hengellisten laulujen kokoelmansa esipuheessa, miten hän käyttää runomitan, tavumäärien ja riimin esikuvana ranskalaisia lauluja (Forsius 1608, 1-2; Lehtonen, tulossa). Vuonna 1624 julkaistuista saksalaisen Martin Opitzin runomuotoja käsittelevistä ohjeista tuli yleisesti omaksuttuja normeja laajalti myös Itämeren piirissä: ne määrittelivät paljon entistä tiukemmin sen, minkälaisin periaattein hyvä runosäe ja riimi tuli rakentaa, ja vaikuttivat myös suomenkielisen kirjallisen runon ihanteisiin. Aikakauden suomalaiset oppineet kokeilivat erilaisia muotoja: riimillisiä säkeistömuotoja, riimillisiä kalevalamitan kaltaisia muotoja ja paikoin riimittömiä antiikin mittojakin. Runomittojen käyttötavoissa oli eroja myös yksittäisten kirjoittajien välillä. (Melander 1928, 1941.) Runouden piirteiden erilaisia yhdistelmiä ja käyttötapoja kokeiltiin. Tätä koskevia keskusteluita ei ole juuri tallentunut, joten rekistereiden arvottamista koskevat tulkinnat perustuvat pitkälti tietoihin siitä, miten erilaisia runouden rekistereitä on säilyneissä lähteissä käytetty.

Annamari Sarajas (1956) vakiinnutti käsityksen kalevalamitasta pakanallisena jäänteenä, jota uuden ajan alun oppineet pyrkivät karsimaan. Tälle käsitykselle on vain epäsuoria lähteitä: Agricola listaa pakanalliset jumalat, joista moni yhä esiintyy 1800-luvun kalevalamittaisessa runoudessa, Finno haluaa korvata kansan paheelliset laulut ja hän välttää virsissään kalevalamitan piirteitä, piispat Rothovius ja Petraeus tuomitsevat loitsut ja siinä sivussa ehkä muitakin maallisia lauluja. Yhtään suoraan kalevalamittaan kohdistuvaa, runomuodon pakanalliseksi nimeävää tai sen kaikkinaisen käytön tuomitsevaa lähdettä ei kuitenkaan ole. Se, että kalevalamitta - nelipolvinen, säkeistötön, riimitön runomuoto - ei koskaan tullut luterilaisen 
virren muodoksi, ei ole välttämättä osoitus sen yleisemmästä paheksunnasta. Olisi ollut radikaali teko irtautua reformaation keskeisrekisterin kosmopoliittisesti, yli kielirajojen jaetuista tunnuspiirteistä eli riimistä, jambimitoista ja säkeistömuodosta niihin liittyvine sävelmineen. Kosmopoliittiseen valtavirtaan liittyminen ei sinänsä ole merkki kotoperäisen muodon paheksunnasta. Sananlaskuissa kalevalamitta sopi kirkonmiestenkin käyttöön, ja sen riimillisiä mukaelmia tehtiin Hemminki Maskulaisen virsikirjan esipuherunosta lähtien. (Kallio et al. 2017, 344-367.) Voi myös olla, että riimillinen versio kalevalamitasta hahmotettiin kirjallisempana tai nykyaikaisempana kuin riimitön.

Suullinen kalevalamitta oli laaja-alainen ilmaisurekisteri, joka kattoi monta lajia ja käyttöyhteyttä (Tarkka 2005, 40). Laajan käyttöalansa vuoksi suullisen runon mitta ei luultavasti assosioitunut mihinkään yksiselitteisiin vaikkapa pakanallisiin tai katolisiin merkitysyhteyksiin. Mahdollisesti käsitykset kalevalamitan luonteesta, joustavuudesta ja sopivuudesta eri yhteyksiin myös vaihtelivat käyttöyhteyksittäin, vuosikymmenittäin ja henkilöittäin.

Ilo-laulun esipuhe on yksi niitä harvoja lähteitä, jossa eksplisiittisesti sanotaan jotain kalevalamitan käytöstä. Salamnius katsoi tarpeelliseksi puolustaa mittavalintaansa, ja samassa yhteydessä hän alleviivaa myös Turun uuden piispan, Johannes Gezelius nuoremman osuutta teoksen synnyssä. Hän näyttää ennakoivan osan mahdollisesta lukijakunnastaan voivan suhtautua runomuodon valintaan torjuen ja pyrkii näyttämään, että runomuodossa itsessään ei ole vikaa, vaikka "tämän caltaisten Runolauluin cautta on ennen monta luvatoinda Asia coconpandu ja laulettu". Maininta on harvinainen säilynyt puheenvuoro runokielten rekisteriytymistä koskevassa keskustelussa, josta osa on voitu käydä suullisesti tai ainoastaan konkreettisina runokielten käyttämisen tekoina. Salamniuksen proosaesipuhe on suunnattu oppineille lukijoille: kansanomaisemmin teos esitellään nimiösivun kalevalamittaisessa otsikkotekstissä: ilolaulu, lohdutus, hyvä sanoma Jeesuksen kuolemasta,

Ylösnoususta iloinen

Paras poijes Lähdennostä

Suomen Kielellä sanottu

Suomalaisten suosioxi.

Oppimattomalle lukijalle riitti runon lajin ja sisällön runomuotoisen luonnehdinnan ohella maininta kielivalinnasta ja kohdeyleisöstä, oppineille taas oli syytä kirjoittaa pidempi esipuhe ja sen yhteydessä myös perustella runomuodon käyttö. Salamniuksen esipuhe viittaa siihen, että oppineen yleisön kannalta kansanomaisen runorekisterin kristillinen kirjallinen käyttö ei ollut itsestään selvästi soveliasta.

Viimeistään Salamniuksen kaksi runoa ja Gezeliuksen auktorisointi näyttävät vahvistaneen riimittömän suullisen kaltaisen kalevalamitan sopivuuden myös kristillisiin ydinaiheisiin ja laajalevikkisiin painotuotteisiin. Salamniuksen jälkeen riimitöntä mittaa ja mainintoja kansanrunosta alkaa näkyä muuallakin (ks. Niinimäki 2007, 307; Sarajas 1956, 180-185). Runon nopeasta hyväksymisestä saattaa osaltaan kertoa sekin, että Salamniuksen oppinutta, antiikin filosofeihin ja Raamattuun viittaavaa, runomuodon valintaa puolustavaa esipuhetta ei enää painettu seuraaviin painoksiin: sille ei näytä olleen tarvetta. Sen sijaan teoksen loppuun liitettiin eräissä 1700-luvun painoksissa Hemminki Maskulaisen Piae Cantiones -suomennoksen virsi "Kijstan kyll mennän juoxeman" (In stadio laboris). (Bastman ja Kallio, tulossa.) 
Porthan käytti vielä 1700-luvun lopulla runoa esimerkkinä taidokkaasta suomalaisesta runosta. Ajan kuluessa sekä teokseen että sen käyttämään runomuotoon liitetyt mielikuvat kuitenkin muuttuivat. Vuonna 1836 Turun tuomiokapituli, jonka vastuulla sensuurin valvonta oli, ei myöntänytkään julkaisulupaa Salamniuksen runolle. Teoksesta oli J. C. Frenckellin painattamana ilmestynyt painoksia vuosina 1818, 1825 ja 1828. Tuomiokapitulin mukaan syynä olivat painoksen lukuisat kielivirheet sekä se, että runossa Jeesuksen elämä esitettiin satuna. (Laine 1997, 216-217.) Nähtävästi kalevalamitta ja tietyt piirteet runon sisällössä saattoivat varjoon sen, että runo pohjaa evankeliumitekstiin ja seuraa paikoittain jopa sanatarkasti Mikael Agricolan Passion (1549) kärsimyshistoriaa, jossa on sovitettu yhteen neljän evankeliumin kuvaus Jeesuksen kärsimyksestä ja kuolemasta. Runon taustan ja tarkoituksen selittävä esipuhe olisi saattanut jälleen olla tarpeen. Tuomiokapitulin sensorin silmissä IloLaulu yhdistyi ensisijaisesti kansanrunouteen ("satuna"), ei evankeliumitekstiin nojaavaan kristilliseen epiikkaan tai passiorunouteen. Taustalla saattoi vaikuttaa sekin, että kalevalamitan status ja siihen liittyvät mielikuvat olivat sensuuripäätöksen aikaan muutoksessa: Elias Lönnrotin Kalevalan ensimmäinen painos oli ilmestynyt vuotta aiemmin.

Kalevalan myötä itämerensuomalainen vanha runomitta assosioitui vahvasti pakanallisia ja sankarillisia muinaisaikoja kuvaavaksi ymmärrettyyn kansalliseepokseen. 1800-luvun Suomessa suullinen runous ja sen pohjalta luotu kirjallinen eepos loivat uutta suurta traditiota, joka nähtiin kansallisen itseymmärryksen kivijalkana, puuttuvan kirjallisen perinteen ja kansallisen historian korvaajana ja osana maailmankirjallisuutta (Anttonen ja Kuusi 1999; Piela et al. 2008). 1800-luvun uudenlaisen kirjallisen suomenkielisen kulttuurin luomisprosessissa runouden lajit ja runokielen rekisterit saivat jälleen erilaisia painoarvoja ja uusia käyttötapoja.

\section{Vernakulaarin monta tasoa}

Matthias Salamniuksen teos Ilo-laulu Jesuxesta asettuu monisyisellä tavalla suhteessa suomenkielisten runomuotojen ja kirjallisuuden lajien kehityskulkuihin sekä suhteessa suulliseen ja kirjalliseen, kansanomaiseen ja institutionaaliseen, kansankieliseen ja kosmopoliittiseen, paikalliseen ja transnationaaliin kulttuuriin. Näiden käsiteparien alkuosia voi kuvata myös vernakulaarin käsitteellä, jota on eri oppialoilla määritetty erilaisin sanan etymologiasta juontuvin tavoin. Salamniuksen runon kohdalla vernakulaari toimii hyvin sekä kirjallisuuden kansankielistymistä että kansanomaista suullista kulttuuria ja sen ilmaisutapoja kuvaavana käsitteenä. Tarkempi analyysi ja käsitteen käyttö kummassakin yhteydessä edellyttää kuitenkin hienojakoisempia määreitä: yleisluonteinen kansankielisyyden, epävirallisen ja hierarkkisesti alisteisen yhdistelmä ei käytännössä erottele riittävästi.

Ilo-Laulun suhde vernakulaareja koskeviin keskusteluihin ei ole yksiselitteinen. Alexander Beecroftin termein runo sijoittuu ennemminkin kirjallisuudellistumisen eli kaunokirjallisen ilmaisun välineiden luomisen kuin kirjallistumisen eli kirjallisen ilmaisun perusedellytysten luomisen piiriin. Teos edustaa omana aikanaan arvostettua raamatullisen epiikan lajia ja lukeutuu osaksi kirjallista korkeakulttuuria. Samalla se kuitenkin kytkeytyy luterilaisen kansanopetuksen perusjuonteisiin: tarkoitus on kiittää Jeesusta, ylistää häntä kaikilla kielillä ja lisätä hänen tuntemustaan "yxinkertaisen cansan tykönä". Salamnius välittää uskonnollisia keskeissisältöjä mahdollisimman helposti omaksuttavassa muodossa: perinteisellä suomalaisella runomitalla. Paitsi kansankielistää, hän siis myös kansanomaistaa ja tekee mahdolliseksi suullisenkin välittymisen - ja olemassa olevan suullisen kansanomaisen kulttuurin haastamisen tai muokkaamisen. Perinteisellä runomitalla oli valmiina moninaisia 
yhteisöllisiä käyttö- ja esitystapoja, ja sillä tehty kirjallinen runo - tai sen osat - saattoi myös välittyä suullisesti ja tulla käytetyksi muiden runojen sijasta. Samalla Salamnius myös siirtää suullisen runomuodon osaksi kirjallisuuden keinovaroja. Beecroftin analyysissa tällaista jo olemassa olevien suullisten, kaunokirjallisiin rinnastuvien keinovarojen käyttöä kirjallisuudellistumisen prosessissa ei tarkemmin käsitellä.

Myöhemmän aineiston sekä loitsuja käsittelevien 1600-luvun oikeustapausten valossa on selvää, että Salamniuksen aikaan suullisessa käytössä oli myös moninaisia keskiajan kristillisyyteen viittaavia kalevalamittaisia runoja ja aihelmia. On mahdollista, että Salamniuksen yhtenä tarkoituksena oli antaa käyttöön luterilainen, puhdasoppinen, laulettavaksi sopiva, kansan omalla runokielellä kirjoitettu teos, joka voisi osaltaan korvata sopimattomampia tai vääriä käsityksiä sisältäviä suullisia lauluja. Tämä ei kuitenkaan tarkoita sitä, että hän tai muut olisivat tuominneet kaiken kalevalamittaisen perinteisenkään laulun. Runolaulun kenttä oli laaja ja monilajinen.

Ilmaisumuodon analyysissa vernakulaarin käsitteen hyvä puoli on, että se ei määritä muotoa käyttävää yhteisöä yhtä yksiselitteisesti kuin vaikkapa kansanrunon käsite. Uuden ajan alun lähteet eivät anna kattavaa todistusta siitä, ketkä kaikki ja miten kalevalamittaista suullista (vernakulaaria) runoa käyttivät. Etenkin pohjalaisten 1600-luvun loppupuoliskon pappismiesten halu käyttää riimitöntä kalevalamittaa kirjallisena keinona joka tapauksessa näyttää, että he kokivat mitan tärkeäksi ja halusivat siirtää sen myös omaan kirjalliseen käyttöönsä. Vernakulaaria - yhtä lailla kansankielistä, kansanomaista kuin suullistakin - runomuotoa voidaan käyttää myös institutionaalisen, oppineen ja kirjallisen kulttuurin piirissä, mikä puolestaan voi heijastua takaisin suullisen ja epäinstitutionaalisen suuntaan. Ilo-Laulun tapaus punoutuukin osaksi monisyistä liikettä suullisen ja kirjallisen, oppineen ja kansanomaisen välillä. Se on myös osa prosessia, jossa kalevalamitan ja riimillisen runouden rajoja ja sävyjä määritetään ja luodaan.

1500-luvulta 1900-luvulle ulottuvassa jatkumossa omaksi ymmärretyistä itämerensuomalaisista perinteistä valikoitiin ja muunneltiin ilmaisutapoja, repertuaareja ja rekistereitä osaksi oppineita, uskonnollisia, kansallisia ja kirjallisia traditiota. Valikoitaessa määriteltiin kulttuurisia arvoja ja hierarkioita. Prosessi oli kaksisuuntainen: valintoja ja tulkintoja tehtiin myös suullisen kulttuurin piirissä. Vernakulaaria voi käyttää myös käsitteenä, joka tuo näkyviin runouden ja runomuotojen muutosten taustalla vaikuttavia kulttuurisia prosesseja, kuten kielten, väestöryhmien ja ilmaisutapojen hierarkioita ja näiden väliseen vuorovaikutukseen heijastuvia asetelmia.

Poeettisten piirteiden analyysi tarjoaa mahdollisuuden tarkastella kulttuurista omaksumista ja vaihtoa eri ilmaisumuotojen ja niitä harjoittavien ryhmien välillä. Varhaismodernin ajan Suomessa toimineet oppineet ja kirkonmiehet omaksuivat ja sovelsivat ylirajaisia kirjallisen kulttuurin ihanteita laulettuun virsirunouteen. Samanaikaisesti suullisen runouden piirteitä omaksuttiin eri tavoin uskonnollisen runouden ja laulun käyttöön. Voidaan puhua prosessista, jossa hierarkkisessa kulttuurissa omaksutaan, omitaan ja vaihdetaan ilmaisun keinoja. Vaihtuessaan ne kantavat konnotaatioita aiemmasta käyttöyhteydestään, mutta niiden kantamat merkitykset muuntuvat uusien käyttöyhteyksien myötä. Vernakulaareja ilmaisutapoja voivat soveltaa yhtä lailla eliitin jäsenet kuin yhteinen rahvas. Periaatteessa jokin piirre kuten riimi voi myös itse saada aikojen saatossa uuden konnotaation: aluksi muunkielisistä ja usein kirjallisista yhteyksistä omaksuttu poeettinen keino vakiintuu suulliseen kulttuuriin 
ja lopulta muuntuu jos ei suullisen niin ainakin "populaarin" ilmaisun tunnuspiirteeksi. Tässä vernakulaarin käsite avaa uudenlaisen mahdollisuuden tutkia ilmaisutapoja, kulttuurisia hierarkioita, vaihtoa ja muutoksia.

\section{Tutkimusaineistot}

Agricola, Mikael. 1549. Se meiden herran Jesusen Christusen pina, ylesnousemus ia taiuasen astumus. Tukholma: A. Laurentsson.

Finno, Jacobus. 1988. Jaakko Finnon virsikirja, toimittanut Pentti Lempiäinen. Helsinki: Suomalaisen Kirjallisuuden Seura.

Forsius, Sigfrid Aronus. 1608. Någhra Nyia Psalmers, Loff-sångers ach Andelighe wijsors Thoner. Hwilke finnes $j$ then lille Psalmboken, som nw är tryckt. Stockholm: Andreas Gutterwitz.

[Gottlund, C. A.]. 1847. Laulu Klaus Kurjen Surmaamasta Eliinasta. Turku: J. C. Frenckell ja Poika.

Porthan, Henrik Gabriel. 1983 [1766-78]. Suomalaisesta runoudesta. Helsinki: Suomalaisen Kirjallisuuden Seura.

Porthan, Henrik Gabriel. 1766. Dissertationis de poësi Fennica, particula prima [...]. Åbo: Frenckell. Digitoitu versio: http://urn.fi/URN:NBN:fi-fd2014-00004879

Salamnius, Matthias. 1690. Ilo-Laulu Jesuxesta. Turku: Johan Winter. Digitoitu versio: http:// urn.fi/URN:NBN:fi-fd2017-00012193.

SKVR. 1908-1997. Suomen Kansan Vanhat Runot. Useita toimittajia. Helsinki: Suomalaisen Kirjallisuuden Seura. http://www.skvr.fi.

\section{Kirjallisuus}

Agha, Asif. 2004."Registers of Language."Teoksessa A Companion to Linguistic Anthropology, toimittanut Alessandro Duranti, 23-45. Malden: Blackwell.

Agha, Asif. 2007. Language and Social Relations. Cambridge: Cambridge University Press.

Ahlqvist, August. 1877. Suomen kielen rakennus: vertaavia kieliopillisia tutkimuksia. I. Suomalainen Runo-oppi. Helsinki: Suomalaisen Kirjallisuuden Seura.

Anttonen, Pertti J. ja Matti Kuusi. 1999. Kalevala-lipas. Uusi laitos. Helsinki: Suomalaisen Kirjallisuuden Seura.

Arner, Lynn. 2013. Chaucer, Gower, and the Vernacular Rising: Poetry and the Problem of the Populace After 1381. University Park, Pennsylvania: Pennsylvania State University Press.

Bauman, Richard. 2016. "The Philology of the Vernacular." Teoksessa Grand Theory in Folkloristics, toimittanut Lee Haring, 63-70. Bloomington: Indiana University Press.

Bastman, Eeva-Liisa. 2019. "Jäljittelyn ja muuntelun dynamiikkaa Matthias Salamniuksen runossa Ilo-Laulu Jesuxesta". Kirjallisuudentutkimuksen aikakauslehti Avain 16(3): 6-23. https://doi.org/10.30665/av.82789 
Bastman, Eeva-Liisa ja Kallio, Kati. Tulossa. "'Turning Simple Speech Into Beautiful Song': Imitative Poetics and the Combination of Registers in Ilo-Laulu Jesuxesta (1690)." Teoksessa Networks, Poetics and Multilingual Society in the Early Modern Baltic Sea Region, toimittaneet Tuomas M. S. Lehtonen, Kati Kallio, Anu Lahtinen ja Ilkka Leskelä. Leiden: Brill.

Beecroft, Alexander. 2015. An Ecology of World Literature From Antiquity to the Present Day. London \& New York: Verso.

Brown, Christopher Boyd. 2005. Singing the Gospel: Lutheran Hymns and the Success of the Reformation. Cambridge (Mass.): Harvard University Press.

Burke, Peter. 2004. Languages and Communities in Early Modern Europe. Cambridge: Cambridge University Press.

Copeland, Rita. 1991. Rhetoric, Hermeneutics, and Translations in the Middle Ages: Academic Traditions and Vernacular Texts. Cambridge: Cambridge University Press.

Cullhed, Anders. 2002. Mimesis förvandlingar: tradition och förnyelse i renässansen och barockens litteratur. Stockholm: Atlantis.

Finnegan, Ruth. 1977. Oral Poetry: Its Nature, Significance and Social Context. Cambridge: Cambridge University Press.

Gioa, Ted. 2011. The History of Jazz. Second Edition. Oxford \& New York: Oxford University Press.

Green, Archie. 1993. "Vernacular Music: A Naming Compass". The Musical Quarterly 77(1): 35-46. https://doi.org/10.1093/mq/77.1.35.

Grönstrand, Heidi, Ralf Kauranen, Olli Löytty, Kukku Melkas, Hanna-Leena Nissilä ja Mikko Pollari. 2016. Kansallisen katveesta. Suomen kirjallisuuden ylirajaisuudesta. Helsinki: Suomalaisen Kirjallisuuden Seura.

Hansson, Stina. 2000. Från Hercules till Swea. Den litterära textens förändringar. Göteborg: Göteborgs universitet.

Heininen, Simo. 2007. "Abckirian sisältö ja lähteet." Teoksessa Mikael Agricola: Abckiria. Kriittinen editio, toimittanut Kaisa Häkkinen, 42-61. Helsinki:Suomalaisen Kirjallisuuden Seura.

Heikkilä, Tuomas. 2010. "Kirjallistumisen jäljillä." Teoksessa Kirjallinen kulttuuri keskiajan Suomessa, toimittanut Tuomas Heikkilä, 11-66. Helsinki: Suomalaisen Kirjallisuuden Seura.

Herl, Joseph. 2004. Worship Wars in Early Lutheranism: Choir, Congregation, and Three Centuries of Conflict. Oxford: Oxford University Press.

Howard, Robert Glenn. 2008. "The Vernacular Web of Participatory Media." Critical Studies in Media Communication 25(5): 490-513.

Häkkinen, Kaisa. 2012a. "The Rise of the Literary Finnish." Cahiers d'Études Hongroises et Finlandaises 18: 11-17.

Häkkinen, Kaisa. 2012b. "Johdatus Mikael Agricolan runoihin." Teoksessa Mikael Agricolan runokirja, toimittanut Kaisa Häkkinen, 9-48. Turku: Turun yliopisto.

Häkkinen, Kaisa. 2015. Spreading the Written Word: Mikael Agricola and the Birth of Literary Finnish. Helsinki: Suomalaisen Kirjallisuuden Seura. https://doi.org/10.21435/sflin.19 
Hämäläinen, Niina, Kati Mikkola, Eija Stark ja Ilona Pikkanen. 2020. "Miten kansasta tulee vernakulaari? Kansanrunoudentutkimuksen, kirjallisuushistorian ja kansankirjoittajien tutkimuksen kansakuva 1820-luvulta 2010-luvulle." Elore 27(1). https://doi.org/10.30666/elore.89069

Jay, Paul. 2010. Global Matters: The Transnational Turn in Literary Studies. Ithaca: Cornell University Press.

Kallio, Kati 2016. “Changes in the Poetics of Song during the Finnish Reformation."Teoksessa Re-forming Texts, Music and Church Art in the Early Modern North, toimittaneet Tuomas M. S. Lehtonen ja Linda Kaljundi, 125-155. Amsterdam: Amsterdam University Press.

Kallio, Kati 2017. "Literary Kalevala-Metre and Hybrid Poetics in the 16th and 17th Century Finland." Folklore: electronic journal of folklore 67: 13-48. https://doi.org/10.7592/ FEJF2017.67.kallio

Kallio, Kati, Tuomas M. S. Lehtonen, Senni Timonen, Irma-Riitta Järvinen ja Ilkka Leskelä. 2017. Laulut ja kirjoitukset: suullinen ja kirjallinen kulttuuri uuden ajan alun Suomessa. Helsinki: Suomalaisen Kirjallisuuden Seura. http://dx.doi.org/10.21435/skst.1427.

Koski, Kaarina. 2016. "The Legend Genre and Narrative Registers". Teoksessa Genre - Text - Interpretation: Multidisciplinary Perspectives on Folklore and Beyond, toimittaneet Kaarina Koski, Frog ja Ulla Savolainen, 113-136. Helsinki:SKS. https://doi.org/10.21435/ $\underline{\text { sff.22 }}$

Koski, Kaarina ja Riikka Turtiainen. 2020. "Vernakulaari verkossa: vertaisuuden ilmaisemisen digitaaliset ulottuvuudet." Elore 27(1). https://doi.org/10.30666/elore.88834

Krohn, Julius. 1862. Suomenkielinen runollisuus Ruotsinvallan aikana ynnä kuvaelmia suomalaisuuden historiasta. [Helsinki]: [Julius Krohn].

Kuha, Miia. 2016. Pyhäpäivien vietto varhaismodernin ajan Savossa (vuoteen 1710). Jyväskylä: Jyväskylän yliopisto. http://urn.fi/URN:ISBN:978-951-39-6598-3

Kurvinen, Onni. 1941. Vanha virsikirja: Vuoden 1701 suomalaisen virsikirjan synty ja sisällys. Rauma: Länsi-Suomen kirjapaino.

Kurvinen, P. J. I. 1929. Suomen virsirunouden alkuvaiheet v:een 1640. Helsinki: Suomalaisen Kirjallisuuden Seura.

Kuusi, Matti. 1998. "Salamnius, Matthias." Teoksessa Kansallisbiografia-verkkojulkaisu. Helsinki: Suomalaisen Kirjallisuuden Seura. http://urn.fi/urn:nbn:fi:sks-kbg-002340.

Laine, Tuija (toim.). 1997. Vanhimman suomalaisen kirjallisuuden käsikirja. Helsinki: Suomalaisen Kirjallisuuden Seura.

Laine, Tuija. 2007. "Winter, Johan." Teoksessa Kansallisbiografia-verkkojulkaisu. Helsinki: Suomalaisen Kirjallisuuden Seura. http://urn.fi/urn:nbn:fi:sks-kbg-002985.

Laine, Esko M. ja Tuija Laine. 2010. "Kirkollinen kansanopetus." Teoksessa Huoneentaulun maailma. Kasvatus ja koulutus Suomessa keskiajalta 1860-luvulle, toimittaneet Jussi Hanska ja Kirsi Vainio-Korhonen, 258-306. Helsinki: SKS.

Laitinen, Heikki. 2006. "Runolaulu." Teoksessa Suomen musiikin historia 8: Kansanmusiikki, toimittaneet Anneli Asplund, Petri Hoppu, Heikki Laitinen, Timo Leisiö, Hannu Saha ja Simo Westerholm, 14-79. Helsinki: Werner Söderström.

Laitinen Heikki. 2005. "Barokki tunteen ja järjen dialogina: Hemminki Maskulaisen Uscovaisen sielun halu Christuxen jälken." Teoksessa Hymnos. Soukat sanat maistaa suu. Hemminki Maskulaisen virsikirja 400 vuotta, toimittanut Reijo Pajamo, 143-163. Helsinki: Hymnologian ja liturgiikan seura. 
Laitinen, Lea ja Kati Mikkola 2013: Kynällä kyntäjät: kansan kirjallistuminen 1800-luvun Suomessa. Helsinki: Suomalaisen Kirjallisuuden Seura.

Launis, Armas. 1930. Suomen kansan sävelmiä. Karjalan runosävelmät. Helsinki: Suomalaisen Kirjallisuuden Seura.

Lauerma, Petri. 2012. Rudimenta linguae Finnicae breviter delineata: suomen kielen varhaiskielioppi ja sen tausta, alkutekstin editointi ja suomennos Suvi Randén. Helsinki: Suomalaisen Kirjallisuuden Seura.

Lehtonen, Heini. 2015. Tyylitellen. Nuorten kielelliset resurssit ja kielen sosiaalinen indeksisyys monietnisessä Helsingissä. Helsinki: Helsingin yliopisto. http://urn.fi/ URN:ISBN:978-951-51-1333-7

Lehtonen Tuomas M. S. Tulossa. "Catholic Heritage, Lutheran Networks and Family Reputation: the Case of the Piae Cantiones Collection (1582-1625)."Teoksessa Networks, Poetics and Multilingual Society in the Early-Modern Baltic Sea Region, toimittaneet Tuomas M. S. Lehtonen, Kati Kallio, Anu Lahtinen ja Ilkka Leskelä. Leiden: Brill.

Lehtonen, Tuomas M. S. 2016. "Pious Hymns and Devil's Music: Michael Agricola (c. 15071557) and Jacobus Finno (c. 1540-1588) on Church Song and Folk Beliefs." Teoksessa Re-Forming Texts, Music and Church Art in the Early Modern North, toimittaneet Tuomas M. S. Lehtonen ja Linda Kaljundi, 179-216. Amsterdam: Amsterdam University Press.

Lehtonen, Tuomas M. S. ja Kati Kallio. 2017. "Petrus Melartopaeuksen kirjeet ja virsisuomennokset: seremoniat, kansanusko ja runokieli 1500- ja 1600-luvun Suomessa." Suomen kirkkohistoriallisen seuran vuosikirja 106: 168-202.

Lemke, Sieglinde. 2009. The Vernacular Matters of American Literature. London: Palgrave.

Leppänen, Katarina. 2018. "Semiperifera anteckningar: en diskussion om regionens plats i världslitteraturen." Tidskrift för litteraturvetenskap 48(1-2): 82-89.

Lilius, Pirkko. 1994. Språkval och ordval i tillfällesdiktningen i Finland 1700-1749. Helsingfors: Svenska litteratursällskapet i Finland.

Lilja, Eva. 2006. Svensk metrik. Stockholm: Svensk Akademien.

Luukkanen, Tarja-Liisa. 2016. Mitä maalaiskansa luki? Kirjasto, kirjat ja kirjoja lukeva yhteisö Karstulassa 1861-1918. Helsinki: Suomalaisen Kirjallisuuden Seura.

Melander, Toini. 1928, 1941. Suomalaista tilapäärunoutta Ruotsin vallan ajalta I \& II. Helsinki: Suomalaisen Kirjallisuuden Seura.

Merriam-Webster. Online Dictionary. https://www.merriam-webster.com.

Mikkola, Kati ja Laitinen, Lea. 2013. "Mielen ja kielen muutoksia". Teoksessa Kynällä kyntäjät. Kansan kirjallistuminen 1800-luvun Suomessa, toimittaneet Lea Laitinen ja Kati Mikkola, 413-463. Helsinki: Suomalaisen Kirjallisuuden Seura.

Niinimäki, Pirjo-Liisa. 2007. "Saa veisata omalla pulskalla nuotillansa." Riimillisen laulun varhaisvaiheet suomalaisissa arkkiveisuissa 1643-1809. Helsinki: Suomen etnomusikologinen seura. http://urn.fi/urn:isbn:978-951-44-6851-3

Noyes, Dorothy. 2012. "The social base of folklore." Teoksessa Companion to Folklore, toimittaneet Regina Bendix ja Galit Hasan-Rokem, 13-30. Chichester: John Wiley \& Sons.

Noyes, Dorothy. 2016. Humble Theory: Folklore's Grasp on Social Life. Bloomington: Indiana University Press.

Oxford English Dictionary. Oxford: Oxford University Press. 
Piela, Ulla, Seppo Knuuttila ja Pekka Laaksonen (toim.). 2008. Kalevalan kulttuurihistoria. Helsinki: Suomalaisen Kirjallisuuden Seura.

Pollari, Mikko, Hanna-Leena Nissilä, Kukku Melkas, Olli Löytty, Ralf Kauranen ja Heidi Grönstrand. 2015. "National, Transnational and Entangled Literatures: Methodological Considerations Focusing on the Case of Finland." Teoksessa Rethinking National Literatures and the Literary Canon in Scandinavia, toimittaneet Ann-Sofie Lönngren, Heidi Grönstrand, Dag Heede ja Anne Heith, 2-29. Newcastle upon Tyne: Cambridge Scholars Publishing.

Pollock, Sheldon I. 2000. "Cosmopolitan and Vernacular in History." Public Culture 12(3): 591-625.

Rapola, Martti. 1934."Vanhan runon kuvastelua parissa 1500-luvun virressä." Kalevalaseuran vuosikirja 14: 149-169.

Sarajas, Annamari. 1956. Suomen kansanrunouden tuntemus 1500-1700-lukujen kirjallisuudessa. Porvoo: WSOY.

Stock, Brian. 1983. The implications of literacy: Written language and models of interpretation in the eleventh and twelfth centuries. Princeton (NJ): Princeton University Press.

Tarkka, Lotte. 2005. Rajarahvaan laulu: tutkimus Vuokkiniemen kalevalamittaisesta runokulttuurista 1821-1921. Helsinki: Suomalaisen Kirjallisuuden Seura.

Virrankoski, Pentti. 1968. "Kuka oli Narvan ilolaulun sepittäjä IGHS?" Sananjalka 10: 37-54.

VKS. Vanhan kirjasuomen sanakirja 1985-. Useita toimittajia. Helsinki: Kotimaisten kielten keskus. http://kaino.kotus.fi/vks.

FT Eeva-Liisa Bastman (ORCID 0000-0002-6366-3544) tutkii varhaisen uuden ajan runoutta Suomalaisen Kirjallisuuden Seurassa ja Helsingin yliopistossa. Kolmivuotista tutkimushanketta (2020-2022) rahoittaa Koneen säätiö.

FT Kati Kallio (ORCID 0000-0002-3673-1409) toimii Suomen Akatemian tutkijatohtorina Suomalaisen Kirjallisuuden Seurassa ja Helsingin yliopistossa (hankkeet 308381, 322071 ja 288119).

FT Tuomas Lehtonen (ORCID /0000-0002-4167-9609) on SKS:n pääsihteeri ja Euroopan historian dosentti, joka on tutkinut keski- ja uuden ajan latinankielistä ja vernakulaaria runoutta ja muita tekstejä, käsityksiä inhimillisen toiminnan ehdoista sekä suullisen ja kirjallisen kulttuurin suhteita. Hän johtaa SKS:ssa toteutettavaa hanketta "Kirjoitukset ja laulut: uskon ja ilmaisun rekisterit varhaismodernissa pohjolassa" (Suomen Akatemian rahoituspäätös n:o 288119, 2015-2020). 